\title{
A TERRA: UMA "COMMODITY" COBIÇADA?
}

A terra - seja ela urbana ou para fins agropecuários - vem sendo cada vez mais comprada e vendida em escala internacional. Um relatório do Banco Mundial divulgado em setembro do ano passado indicou que, em 2009, nos países em desenvolvimento, cerca de 45 milhões de hectares foram adquiridos por estrangeiros. Dessa área total, aproximadamente $70 \%$ estão na África. No Brasil, calcula-se que empresas ou pessoas estrangeiras têm adquirido o equivalente a $12 \mathrm{~km}^{2}$ por dia, ou 22 campos de futebol por hora. E a Federação Agrária Argentina estimou que, em 2007, cerca de 270 mil km², ou $10 \%$ do território do país, já estavam nas mãos de investidores estrangeiros.

E os preços começam a aumentar diante da evidência de escassez relativa. Com um agravante: essa commodity não pode ser transferida de lugar nem produzida por quem não a possui. Países de grande população, como a China, ou de pouca terra arável, como a Arábia Saudita, mas cheios da grana, já começam a ultrapassar suas fronteiras em busca desse fator de produção. A necessidade de garantir a segurança alimentar de suas populações leva-os a adquirir terras na África, na América Latina ou na Austrália. Diretamente, ou associando-se com empresários locais, representantes desses países começam a produzir alimentos e matérias-primas no ultramar.

Em países como a China - e também a Índia - a situação torna-se ainda mais complicada, pois a intensa expansão urbana devora o que antes era terra dedicada à agricultura.

O Brasil, nesse campo, tem vantagens consideráveis que o livram dessas pressões. A área agricultável do país chega a mais de $75 \%$ do território. Nos últimos 40 anos, mais de 120 milhões de hectares (cerca de 5,5 vezes a área do Estado de São Paulo) foram incorporados à agropecuária do país, tornando o Brasil campeão de exportações das suas commodities. Terra barata, novas tecnologias, devastação livre e forte demanda externa são fatores que contribuíram para a expansão da fronteira agrícola interna, que ameaça santuários ecológicos de maneira irreversível.

Mas a manutenção dessa vantagem no longo prazo depende basicamente de três condições: a) que a devastação ambiental nos estados do Norte e do Centro-Oeste seja substituída pelo desmatamento zero; b) que o desenvolvimento científico e tecnológico permita aumentos substanciais da produtividade sem aumento de área cultivada; e c) que a infraestrutura de logística e de transportes reduza os custos de armazenagem e fretes. Por exemplo, seria da maior importância um corredor rodoferroviário eficaz para portos do Pacífico visando à redução de fretes para os mercados asiáticos.

Sabemos que exportar commodities não é a melhor alternativa de inserção na economia global. Mas, enquanto não formos capazes de competir com produtos de alta tecnologia e valor agregado, não será um pecado tirarmos proveito dessa invejável vantagem competitiva.
A terra se tornou uma commodity internacional e os preços começam a aumentar diante da evidência de escassez

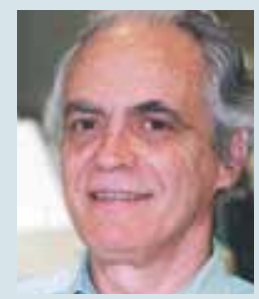

PAULO SANDRONI FGV-EAESP paulo.sandroni@fgv.br 